\title{
IS DIVERSIFICATION OF FARM HOUSEHOLDS STILL AN OPTION FOR INTEGRATED RURAL DEVELOPMENT? EVIDENCE FROM SLOVENIA AND SAARLAND, GERMANY
}

\author{
BirTe Nienaber ${ }^{1}$, IRMa PotoČNik Slavič² \\ ${ }^{1}$ Geography and Spatial Planning Research Centre, University of Luxembourg, Luxembourg \\ ${ }^{2}$ Department of Geography, Faculty of Philosophy, University of Ljubljana, Ljubljana, Slovenia
}

Manuscript received: February 1, 2013

Revised version: September 9, 2013

\begin{abstract}
Nienaber B., РотоČNik Slavič I., 2013. Is diversification of farm households still an option for integrated rural development? Evidence from Slovenia and Saarland, Germany. Quaestiones Geographicae 32(4), Bogucki Wydawnictwo Naukowe, Poznań, pp. 39-48, 1 table, 2 figs. DOI 10.2478/quageo-2013-0032, ISSN 0137-477X.

ABstRAct: Multifunctionality of rural areas in Europe has become an important aspect of rural development in the last years. An important instrument to ameliorate the multifunctionality is diversification of farm income. As various forms of farm income diversification have been developed throughout Europe, the paper will survey the effectiveness of undertaken measures. First the issue of farm diversification will be argued theoretically. Then case studies from Saarland, Germany, and from Slovenia will analyse the importance of diversification for rural areas. A comparison of the two regions will reveal the chances and risks of diversification in a comparable new and old EU member state.
\end{abstract}

KEY WORDS: farm, on- and off-farm income diversification, rural development, Saarland, Slovenia

Birte Nienaber, Geography and Spatial Planning Research Centre, University of Luxembourg, Campus Walferdange, Route de Diekirch (B.P. 2), L-7201 Walferdange, Luxembourg; e-mail: birte.nienaber@uni.lu

\section{Introduction}

In the economically developed countries, the number of farms (farm households) unable to attain an adequate income solely from the agricultural activity has been increasing over the last years (Pieniadz et al. 2009). Development guidelines of the current EU Common Agricultural Policy as well as measures of the European Agricultural Fund for Rural Development (2007-2013) support diversification of farm income. A set of related measures is aimed at provision of additional income for farm households, long-term stabilisation of the population, and consequently more sustainable rural development.
It is the aim of this paper to (1) focus on internal and external factors (i.e. operating on the farm /within the farm household, or outside it) as the dominant push-pull factors for farm income diversification. Evidence from Saarland, Germany, and Slovenia confirms the long-lasting importance of farm income diversification for rural and regional development. Analysed next are (2) various forms of (on-, off-) farm income diversification evolved throughout Europe over the decades as resilience strategies and employed by individual farms, localities, territories, or even internationally. The paper underlines several similarities in the mechanism of farm income diversification and also quite evident differences in their efficiency. And (3), the paper aims to answer the question if farm diver- 
sification is still an option for integrated rural development by using the case study regions as a reference value, but also applying it more generally to other European rural regions.

In the following, the issue of farm income diversification will be argued theoretically. Then a short presentation is given of the geographical settings relevant for the two case study regions, viz. Saarland in Germany and Slovenia. Their comparison will reveal the chances and risks of diversification in a new and an old EU member state. The methodological background is followed by empirical evidence, namely factors and forms of farm income diversification. In the conclusion, the importance of farm income diversification for rural development will be analysed.

\section{Theoretical framework of farm income diversification}

In the field of farm income diversification, a differentiation is made between on-farm and offfarm income diversification. On-farm income diversification connotes the widening of income sources of farm households on the farm. Offfarm income diversification means having a job outside the agricultural area of the holding. The agricultural household is seen as a unit: it is irrelevant whether it is the farmer, the spouse or any other family member living in the household who starts a diversifying activity.

In many studies, mainly those made in the 1990s and early 2000s, only on-farm income diversification is meant by 'diversification', thus excluding off-farm income possibilities (e.g. Gillmor 1995, Cawley et al. 1995, Commins 1996, Maye et al. 2009, López-i-Gelats et al. 2011). The definition of the term 'diversification' has to be clarified. Diversification "is particularly relevant to the farmer whose agricultural resources are insufficient to provide a decent livelihood. [...] Forestry, fishing, tourism and industrial or service employment offer clear opportunities for the small farmer" (Cuddy 1991: 63). Diversification can be a survival strategy for non-competitive farm households. Other factors are named by agricultural sociologists Anosike and Coughenour (1990: 1-2): "First, although a farmer with only one major productive enterprise is specialised, while a farmer with two or more enterprises is diversified, diversification as a successful management strategy is more than the mere addition of enterprises, since the enterprises must be selected with respect to how well they complement existing enterprises and how agroecologically compatible they are. [...] Second, [...] [a]griculture is resource intensive [...], and therefore, the continued viability of a farm depends in part on the farmer's ability to select an appropriate combination of enterprises for a given agroecological environment. By diversifying, the farmer may use resources more efficiently and promote sustainability. Third, understanding diversification facilitates the development of policies to promote structurally diverse family farm organisations. [...] Fourth, diversification is a dimension of farm structure [...]." Lately, the term diversification has been more frequently used in rural studies in Europe following the formulation of CAP measures (the third axis).

Off-farm income diversification was strongly pronounced mostly on small farms which could not sustain all family members merely by the continuing existence of old or employment of new agricultural practices. This process was simultaneous with the emergence of industrialisation in urban areas, later on followed by rural industrialisation and the developing offer of non-industrial working places.

In the last years also pluriactivity of farm households has gained more research focus. Pluriactivity is a multidimensional concept that contains all paid working activities, bilateral working exchange (e.g. neighbourly help), community activities (e.g. voluntary work) as well as informal arrangements. Equivalents for the work done can be in kind, salaries or transfers. The term, however, is also used differently in the literature. Whilst Kinsella et al. (2000), for example, use this term as a synonym for off-farm diversification, Gilg and Battershill (1999) indicate regionally grounded forms of pluriactivity (in Languedoc, Savoi and Pickardie, France). Several forms of pluriactivity have been recognised (Dictionnaire Multilingue ... 1997: 294):

- pluriactivity which includes two different jobs throughout the year, usually referred to as 'double-activity' (for example farmer-worker, merchant-farmer); 
- pluriactivity which merges several jobs which are seasonally subsequent (agriculture, trade, hotel business, tourism, mountaineering activities); and

- pluriactivity where basic agricultural production is complemented with one on-farm diversification activity (farm tourism, direct sale on farm).

The issues of on-farm income diversification have been addressed from diverse perspectives over the last three decades. Besides several theoretical discourses, far more empirical research has been undertaken. In the discourses (Woods 2011) there has been strong support for the concept of multifunctionality. This approach differs from previous ones on the question of what happens to farms that cannot be viably sustained through the free market for agricultural produce. Multifunctionality recognises that such farms have a value to the countryside over and above their production of goods for the mass market, and seeks to enable these wider functions to be valorised in order to achieve economic sustainability. This might mean converting to the production of higher-value agricultural goods or exploitation of the amenity value of farmland through tourism and recreational activities (e.g. Brandth, Haugen 2011; Dubois, Schmitz 2012; Potočnik Slavič 2012), or the commodification of the environmental benefits of farming through the payment of rewards for good stewardship (Talbot 2012), support for initiatives aimed at producing high-quality locally branded food, an assistance with conversion to organic farming, etc. Special light has been thrown on the strategies of farmers attempting to diversify into non-productivist activities. The survival of the family farm in Europe may be credited to the protection of small farmers from full exposure to free market conditions provided by the CAP (Woods 2011).

There are still quite different discourses on whether the above-mentioned mechanisms and forms of farm income diversification contribute to integrated rural development. Since the issues of farm income diversification are quite broad, this paper narrows its scope to mostly on-farm diversification which can be followed and compared using official statistics. With the implementation of the Rural Development Programme (2007-2013), we might monitor the expenditure on selected measures for improving farm diversification across the EU.

It is the aim of this paper to analyse the factors and forms of farm (mostly on-farm) diversification in an old (Saarland, Germany) and a new (Slovenia) EU member state. It is our hypothesis that the factors underlying farm income diversification might be quite similar in both case study regions, whereas its forms might be adapted mostly to the local settings. In the conclusion, the paper aims to answer the question of whether farm diversification is still an option for integrated rural development or if it generates new local/ regional rural disparities.

\section{Geographical settings of Slovenia and Saarland, Germany}

Slovenia (Fig. 1) represents a distinctive transitory country due to its site and location on the crossroads of four European landscape units (Mediterranean, Pannonian, Alpine and Balkan). The $20,273 \mathrm{~km}^{2}$ of national territory differ in terms of climate, vegetation, civilisation, etc. The landscape itself can be described as heterogeneous, mosaic and filigree in structure. In 1991 (the year of the disintegration of Yugoslavia) Slovenia became an independent state. With the population of two million and a relatively low population

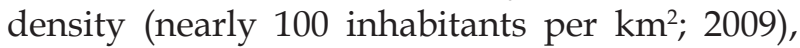
Slovenia ranks as a very rural country (in terms of the OECD methodology on rural areas). Considering its physical geographical conditions, more than $80 \%$ of Slovene territory is classed as less favoured areas for agriculture. $65 \%$ of the territory is covered by forest. Fields are limited to relatively small areas and also threatened by suburbanisation and the expansion of a highway network. In the agricultural land-use structure, grassland dominates absolutely, at more than two-thirds of agricultural land. During the socialist socio-economic regime, Slovene rural areas experienced essential changes since the state preferred industrialisation and urbanisation. As a consequence, rural areas and agriculture had been neglected. The implementation of the maximum-land act (with limited 10 hectares of land per individual private farmer) was followed by an artificially blocked process of enlargement and rounding 
off of farmland. But on the other hand the system supported the establishment of socialised groups of enterprises that would gain necessary land for operation following the nationalisation and rounding off of confiscated land. Compared to other East European countries, a relatively small share (approx. 30\%) had been nationalised and a very important and characteristic picture of Slovene agriculture became apparent: very small and fragmented land plots as a remnant from the mid-19 $9^{\text {th }}$ century. The agricultural census of 2010 recorded 74,646 farms (14\% fewer than in 2000), the average size of a family farm being 6.4 ha AL, mostly oriented towards stock-breeding (SORS 2012). 61\% of farms cultivate less than 5 ha; consequently part-time farms are dominant. Therefore Slovenian agriculture has been facing continuously deteriorating land and farm structure, low work intensity, and (in some areas) the abandonment of cultivation.

With an area of 2,569.68 $\mathrm{km}^{2}$, Saarland (Fig. 1 ) is the smallest German federal state. Liedtke (1969: 10-11) defines its three different landscape formations: flats with monadnocks, cuesta landscapes, and valley landscapes of the Pleistocene. Geologically, Saarland is dominated by shell limestone in the south-east and west. North of these areas red sandstone can be found (Schneider 1991: map). The climate is characterised by a double transition. The region displays great var-

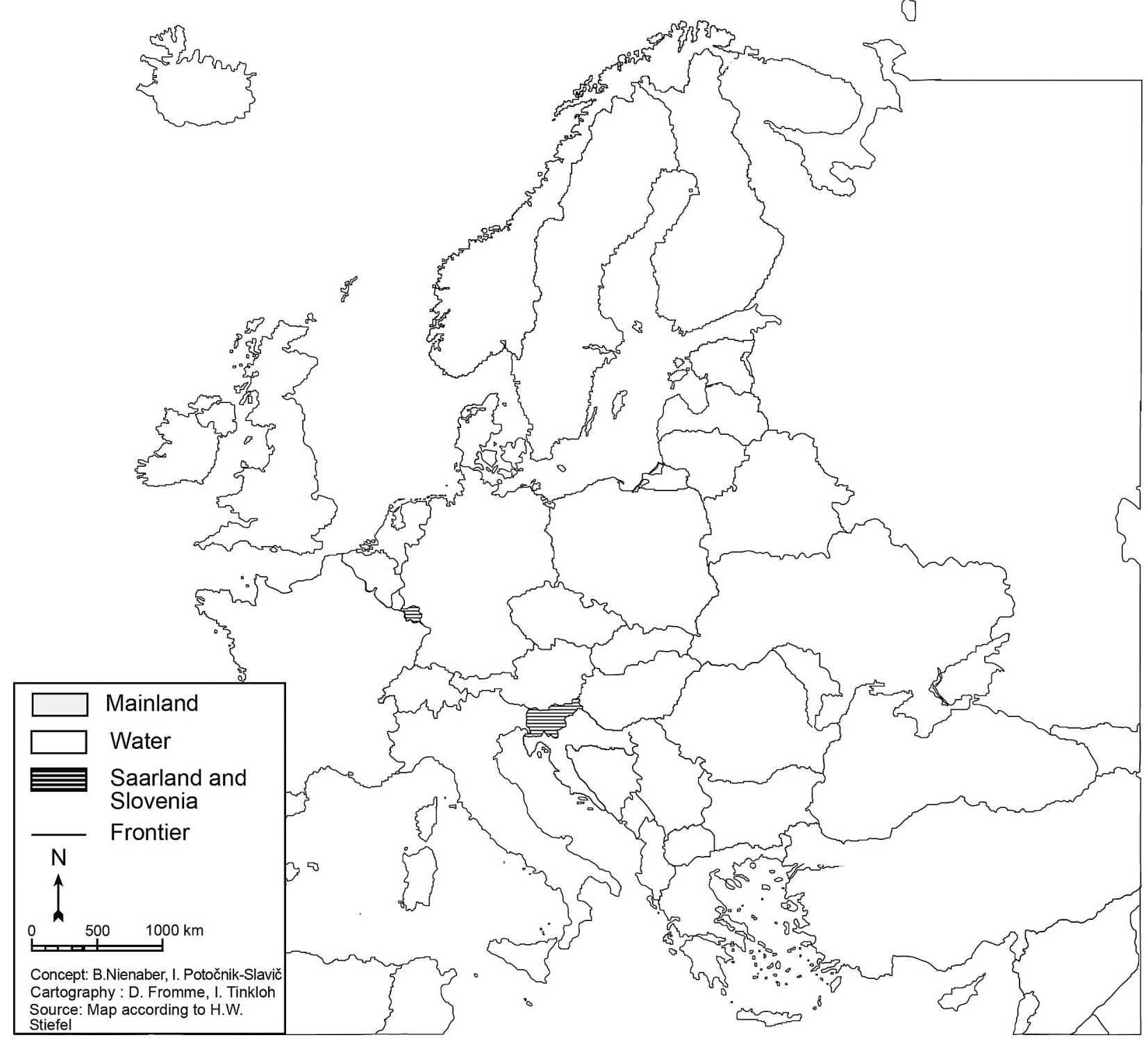

Fig. 1. Location of the case study regions: Saarland, Germany, and Slovenia. Source: own graphics. 
iations in weather conditions, with a contrast between the high, cold forests with high precipitation and the warmer valleys of the rivers Saar and Blies with low precipitation. The other regions of Saarland are transition zones between these two (Kühne 2004: 115). After the Second World War, Saarland was first under the protection of France, then became partly independent but connected with the French economic system. In 1957, after the so-called Saar-Referendum, Saarland became the eleventh federal state of the Federal Republic of Germany. Alongside the river Saar, there is a high-density old industrial area which used to be famous for steel and coal mining. Nowadays, the automobile industry can be found in this region. The northern and south-eastern parts of Saarland are mainly rural. While the average population density in Saarland is 397 inhabitants per $\mathrm{km}^{2}$, the figure for the district of Merzig-Wadern in the north-west is only 189 (the federal state has a total population of 1,012,000; Statistisches Amt Saarland 2012a). Using the OECD methodology on rural areas, Saarland as a whole is defined as 'predominantly urban'. Its agriculture has undergone structural change in the last century. Common until the 1960s was the gavelkind, i.e. an equal split of inheritance among children. That led to a structure of small and smallest farms that mainly provided the owner's family with food. So-called 'working farmers' and 'mining farmers' were the embodiment of agriculture in Saarland (Guth 2007: 177). After the Second World War, the situation was too uncertain for farmers to invest. It changed after the reunification of Saarland with Western Germany in 1957. While in the 1960s there were 28,396 farms in Saarland of which 85\% were less than 5 ha in area, by 2010, after several agricultural reforms in Saarland itself, Germany and the EU, they had been reduced to 1,390 farms with an average of 59 ha and only $8.5 \%$ with under 5 ha (Guth 2007: 181, Statistisches Amt Saarland $2012 b)$. Nowadays the typical full-time farm is a family farm with about 80 ha, while in $200362 \%$ of all farms were part-time ones with an average of $18 \mathrm{ha}$. The main agricultural type is forage farming with a focus on dairy (Guth 2007: 185-187). Between 1999 and 2003, 12.6\% of all farms were abandoned, but the agricultural land in use remained nearly the same. This means that fewer farms cultivate more area per farm (Feist 2004: 3).

\section{Materials and methods}

The on-farm diversification described above, and also implemented under the current Rural Development Programme, could be compared for Germany's Saarland and Slovenia using official statistics. The EU Commission proposed eight measures under Axis 3 ("Quality of life in rural areas and diversification of the rural economy") which fall into two discrete target groups: those aimed at economic development and diversification of the rural economy (measures 311, 312, 313 ), and those referring to a wider rural community (measures 321, 322, 323, 331) and focusing on the quality of life. In the period 2007-2013, the following measures were chosen in both case study areas:

- Diversification into non-agricultural activities (311),

- Support for business creation and development (312),

- Basic services for the economy and rural population (321),

- Village renewal and development (322), and

- Conservation and upgrading of the rural heritage (323).

In the analysis we compared financial means allocated to the above measures. We also included data from in-depth interviews (21 conducted in Slovenia in 2011, and 21 conducted in Saarland in 2009 and 2010) with the beneficiaries of those measures. The information obtained enabled us to get more insight into the factors that had influenced farm income diversification. Even more valuable were the interviewees' personal experiences with the mechanisms, measures and forms of farm income diversification.

\section{Factors generating farm income diversification}

Before 1991, off-farm income diversification strongly prevailed in Slovenia: since the farms were very small, numerous farm members had to find off-farm employment, often a non-agricultural one, but they still cultivated the land after returning from the off-farm job. So-called part-time farmers mostly acquired agricultural produce for their family, some also for the mar- 
ket. The off-farm, regularly gained income was used for family needs, but was also an important source for farm investments. Consequently, they maintained cultural landscape (Klemenčič 2005, Potočnik Slavič et al. 2012, Logar 2012). It was not until the year 2000 that Slovenian farmers started intensively practising various on-farm income diversification. This was recognised as an interesting income source, especially after Slovenia gained independence (1991) and with the implementation of several laws and policies at the national level (Law on Agriculture in 2000, the special Regulation on Supplementary Activities on Farms, the Rural Development Programme) that were strongly influenced or generated by the country's accession to the EU (2004) and by its economic transition. Consequently, today nearly $75 \%$ of farm holders gain income also from other sources (EUROSTAT 2006); this segment of farms has been especially active in looking for additional on-farm income diversification.

Until the 1960s, Saarland was characterised by very small businesses, so-called mineworker's farms. Besides working in a coal mine or as industrial workers, most Saarland people cultivated a very small business, especially on a subsistence basis. Today, due to the agricultural structural changes, those very small businesses have disappeared, but in 2010 more than half of the 1,319 farms were still run by part-time farmers with an off-farm income in the industrial or service sector (Guth 2006, Statistisches Amt Saarland 2012b). In Saarland, on-farm diversification is an option for part- as well as full-time farmers. In 2010, only 24 farms offered agro-tourist activities. In other areas landscape conservation of orchard meadows is part of on-farm diversification and farmer-to-consumer direct marketing. The projects under the European Agricultural Fund for the rural development measure 311 focused on renewable energy, horse pensions as well as farmer-to-consumer direct marketing. Measure 312 for the establishment of very small enterprises was not implemented due to lack of demand.

Special emphasis in both case study areas was put on longitudinal research which included selected rural areas over the past five years. Therefore, qualitative methods were undertaken first of all to investigate prevailing internal and external factors perceived by farmers as the dominant push-pull factors for farm income diversification (Fig. 2). The decision-making process in every single farm household is usually influenced by a complex set of relevant internal and external factors.

"Of course ... our farm household appreciates additional on-farm income (i.e. farm tourism, offering food and beverages), ... but it is not that easy... especially in these days of crisis when everyone states that you cannot afford to have low occupancy rate ... well, but I still consider farm tourism as a supplementary activity on the farm. One could also decide for tourism exclusively, but then you would need to close down the farm and buy everything in the store. I produce milk and cheese and my customers appreciate the authenticity ... and with our facilities we cannot dedicate ourselves to mass production. But otherwise, I cannot employ someone in the stall since I do not gain enough from farm tourism" (female, 51 years, 6 family members, three-generation farm household, Slovenia).

There is a pig farm in the north-east of Saarland. The farmer breeds pigs from birth till slaughtering. Since 2011, this farm has also a show slaughterhouse and a butcher shop on its premises to show interested people, especially groups of kindergarten or school children, what can be produced from pigs and even to market homemade meat products. It is a good combination to have different on-farm diversification strategies at the same time. First, this farm has gone into further processing of its pig meat. Second, its operators now offer their own meat and therefore earn money through direct selling. They also sell other regional products in their shop to have a larger range of goods for their customers. Third, by having a show slaughterhouse, they educate people, especially children, and attract them to the farm on an event basis. Those people may then buy the offered products. The problems for the farmers are the great amount of bureaucratic work and different contact persons and forms at the LEADER level, in the chamber of agriculture and in the federal ministry. The marketing is mainly done by the LEADER initiative, which supports especially direct marketing and selling strategies. The farm owner thinks about reducing his stock of pigs and enhancing on-farm diversification branches. Another possibility can be to diversify into other on-farm stock, like cows, cattle and so on, to go much more into an event and adventure farm. 


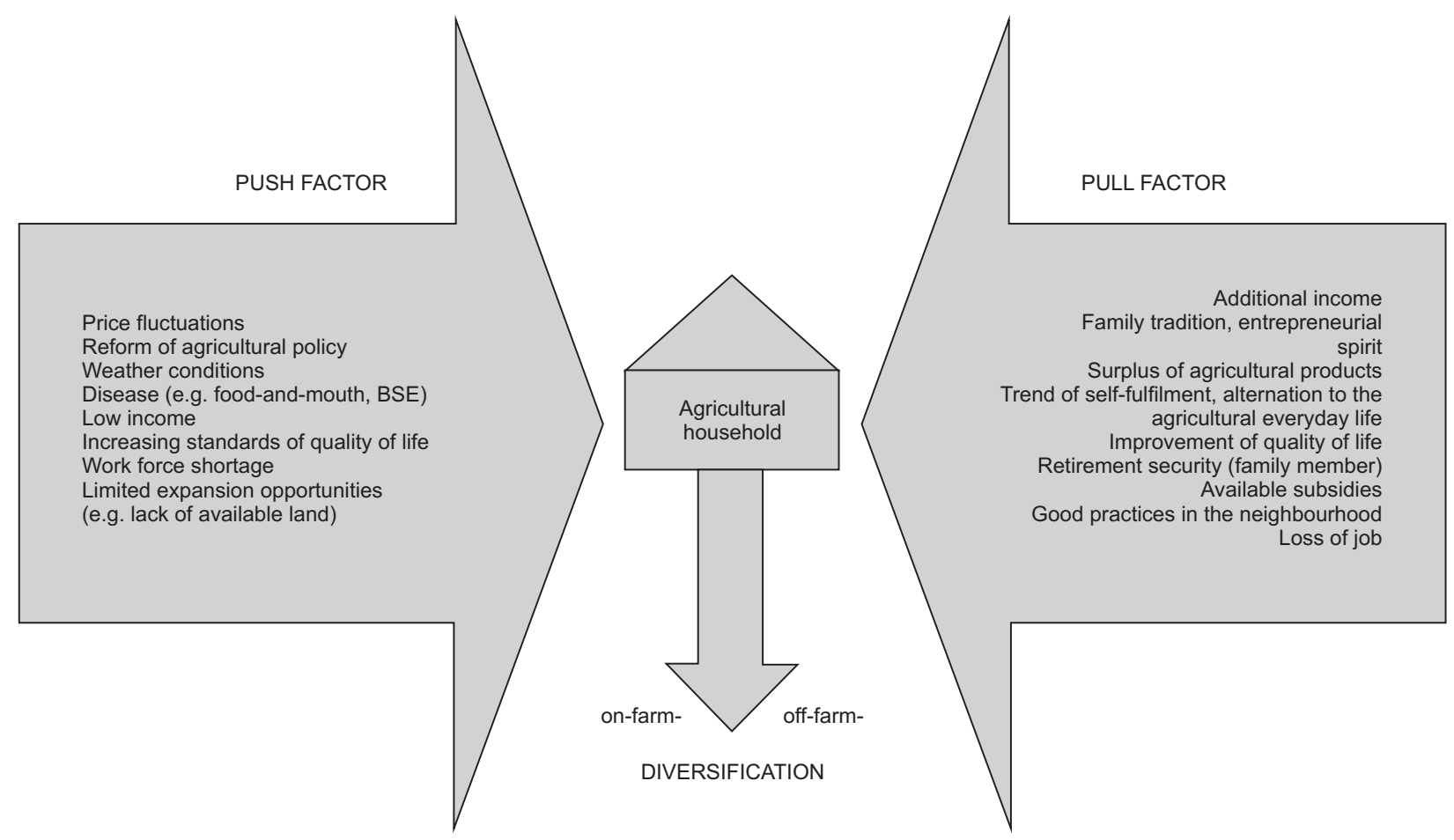

Fig. 2. Relevant push- and pull-factors for diversification of farm income (farmers' perspective). Source: Anosike, Coughenour (1990), Chaplin (2000), Sprenger (2002), Potočnik Slavič et al. (2012).

When analysing the literature as well as the interviews, there appeared some special factors concerning the decision-making process of farm households that push or pull them into diversification. The push factors are mainly uncertainties (e.g. price fluctuations, CAP reforms) and threats (e.g. extreme weather events, animal or crop diseases) as well as personal reasons, like an increase in the standard of living for which the income is too low. The pull factors therefore partly correspond with these push factors as they are often personal reasons (e.g. an additional income), but also connected to business decisions (e.g. the availability of subsidies). After weighing the various pros and cons, the individual farm household decides whether to diversify or not. If the family decides to diversify, there are opportunities for on- and off-farm as described above.

Thus, we have confirmed part of our initial hypothesis that the factors - or set of factors that have generated farm income diversification have been quite similar in old and new EU member states. This seems to be quite understandable since the agrarian structure of the compared areas has some common characteristics. Yet, there are still differences in the time period when the relevant factor occurred (several of them, strongly at- tached to the RDP, occurred earlier in Saarland). Also important is the mentality, flexibility and the individual business situation of each farmer.

\section{Prevailing forms of on-farm income diversification}

With the official data on financial means directed to selected RDP measures, we managed to disclose some differences between our case study areas. Saarland did not put measure 312 into practice - it was given up for lack of interest (Doluschitz et al. 2012, Ministerium... 2012), while in Slovenia no funds were earmarked for measure 321 (ARSKTRP and MKO 2012). The expenditure on all the measures was used as an indicator of on-farm and rural income diversification as well as of rural development as a whole (Table 1).

During the period 2007-2011, Slovenia allocated $€ 35$ mio payments (altogether $€ 47$ mio with national funds) for Axis 3: 55\% were earmarked for Business creation and development, another quarter for Diversification into non-agricultural activities, 17\% for Village renewal and development, and a modest $4 \%$ for Conservation and upgrading of the rural heritage. This distribution 
tried to address the most notable rural development problems in Slovenia, i.e. the shortage of working places (Klemenčič et al. 2008), entrepreneurship being one of the priorities. Measure 312 aims to support the creation and development of micro-enterprises with a view to promoting entrepreneurship and creating employment opportunities. A key objective of the measure is to provide support for growth aspirations of small rural businesses. The rationale for public support is the role that micro-enterprises could play in stimulating economic growth, innovation and competitiveness, in creating employment opportunities, and in their potential as rural social enterprises to help improve access to services and opportunities in the countryside (RDP 2007-2013).

"At the moment, agriculture generates $65 \%$ of income of our farm household, 35\% comes from a supplementary activity (energy provision). We are planning to expand our activities in the field of stock-breeding and forest mechanisation. In our locality the role of woods is of special importance. Since we have an abundance of woods we have decided to give our woods a value added. Consequently, I have decided to invest in energy production from biomass. There were some subsidies, I evaluated (together with my wife - she is an economist) that the energy price would increase in the future. I invested in the infrastructure and am now providing warming solution for the local school, fire brigade facilities, and also some neighbours. Since the price of " $m y$ " energy is much lower, I expect that some other neighbours will join" (male, 35 years, 5 family members, three-generation farm household, Slovenia).

Table 1. Comparison of payments for Axis 3 (Slovenia and Saarland, Germany).

\begin{tabular}{|c|c|c|}
\hline Measure & $\begin{array}{c}\text { Total payments } \\
\text { (1 Jan. 2007-31 Dec. } \\
\text { 2011) from EU funds } \\
\text { in Slovenia }(\boldsymbol{\epsilon})\end{array}$ & $\begin{array}{c}\text { Total payments } \\
\text { (1 Jan. 2007-31 Dec. } \\
\text { 2011) from EU funds } \\
\text { in Saarland }(\boldsymbol{\epsilon})\end{array}$ \\
\hline 311 & $8,588,255$ & 974,225 \\
\hline 312 & $19,295,868$ & 0 \\
\hline 313 & 0 & 360,315 \\
\hline 321 & 0 & 219,470 \\
\hline 322 & $5,906,587$ & 218,3694 \\
\hline 323 & $1,520,348$ & 214,142 \\
\hline Axis 3 & $35,311,059$ & $3,951,846$ \\
\hline
\end{tabular}

Source: Doluschitz et al. (2012), ARSKTRP and MKO (2012).
In Saarland, $€ 8.3$ mio were allocated for rural development measures under the EU Axis 3 during the period 2007-2013. 48\% were only realised between 2007 and 2011 (Doluschitz et al. 2012). The focus was on measure 322 with ca. $€ 2.8$ mio (78\% between 2007-2011) for renewal projects to make villages more attractive, followed by measure 313 strengthening and supporting rural tourist attractions, with a very low level of implementation (25\%). The problem here is lack of investment of the private sector. The third major measure was 311 supporting diversification into non-farm activities, especially renewable energy (implementation level 72\%) (Doluschitz et al. 2010, 2012).

A new small cheese factory can be an activity of tourist interest when diversifying into nonfarm activities or changing farm production. In Saarland, such small cheese factories are newly established and operated by former farmers. This has also implications for other farmers in the region: a new distribution of dairy farms and conversion into new organic regional economic cycles with local farmers, markets and bakeries, and a new tourist attraction (a cheese factory event and a dairy theme trail).

We have also confirmed that farm income diversification differed in the two regions depending on various geographic locations. Inequalities were also generated by differences in the agrarian structure (early farm specialisation in Saarland), special market demands (the demand for farm food and beverages in Slovenia as a strong tourist potential), etc. In Slovenia, there was much stress on supplementary activities on farms (tourism, mechanisation-related services, on-farm processing, etc.) which empowered mostly farm households. In Saarland, supplementary activities were increasingly combined with an event or educational character of the activity as well as the EU-financed mainstream diversification opportunities. 


\section{Conclusion: What is the real contribution of farm income diversification to rural development in the selected case study regions?}

The first and often most visible outcome of farm income diversification is the empowerment of farm households: using various income sources, they usually become more resilient since they also become more entrepreneurial by diversifying into new branches. Moreover, this helps to retain (young) people in rural areas and therefore attenuates the demographic change in Europe's rural regions.

It has been evident in the selected case studies that the diversification of farm income contributes to the vitality of the rural region. Farmers and their households also undertake new societal duties, e.g. by offering renewable energy or education programmes for children. This is part of the multifunctionality idea of rural areas, but it is also a contribution of each farm household and its decision-making processes.

But on the other hand, our field research confirms that new regional disparities are being generated under the existing RDP measures. Rural areas with strong networks, innovative stakeholders and strong rural development policy support are often in a win-win situation. Whereas rural localities unable to apply for EU or national funds (usually demographic and economic structures are poorly developed and social capital rates are low) are becoming more reluctant and ambivalent. A future RDP would have to work out special measures for these areas.

\section{References}

Anosike N., Coughenour C.M., 1990. The socio-economic basis of farm enterprise diversification decisions. Rural Sociology 55(1): 1-24.

ARSKTRP and MKO, 2012. Statistical data on RDP measures expenditure. Ljubljana.

Brandth B., Haugen M., 2011. Farm diversification into tourism - Implications for social identity? Journal of Rural Studies 27 (1): 35-44.

Cawley M., Gillmor D.A., Leavy A., McDonagh P., 1995. Farm diversification: Studies relating to the west of Ireland. Dublin: Teagasc.

Chaplin H., 2000. Agricultural diversification: A review of methodological approaches and empirical evidence. On- line: http://www.ilr.uni-bonn.de/ agpo/rsrch/ Idara/ Farm/ wyewp2.doc (accessed 22 January 2013).

Commins P., 1996. Agricultural production and the future of small-scale farming. In: Curtin C., Haase T., Tovey H. (eds), Poverty in rural Ireland: A political economy perspective. Oak Tree Press, Dublin: 87-125.

Cuddy M.P., 1991. Rural development in Ireland: an appraisal. In: Varley T., Boylan T.A., Cuddy M.P. (eds), Rural crisis. Perspectives on Irish rural development. Centre for Development Studies, University College, Galway: 28-47.

Dictionnaire Multilingue de l'Aménagement du Territoire et du Développement Local, 1997. La maison du dictionnaire, Atea-Cridel, Paris: 171, 195, 294.

Doluschitz R., Grosskopf W., Nienaber B., 2010. ELER. Plan zur Entwicklung des ländlichen Raums im Saarland 20072013 (Rural development plan in Saarland, 2007-2013). Halbzeitbewertung 2007-2009 (Mid-term evaluation 2009). Online: http:// www.saarland.de/ dokumente/ thema_landwirtschaft/ Halbzeitbewertung_02-12-2010. pdf (accessed 22 January 2013).

Doluschitz R., Kühne O., Wojtyniak B., 2012. ELER. Plan zur Entwicklung des ländlichen Raums im Saarland 20072013 (Rural development plan in Saarland, 2007-2013). Laufende Bewertung für das Jahr 2011 (On-going assessment for the year 2011). Online: http:/ / www.saarland. de/ dokumente/ thema_landwirtschaft/ Laufende_Bewertung_zum_Zwischenbericht_2011.pdf (accessed 22 January 2013).

Dubois C., Schmitz S., 2012. What is the position of agritourism on the Walloon tourist market? Agritourism between embeddedness and internationalisation. File of papers: 33-43.

EUROSTAT, 2006. Online: http:// epp.eurostat.ec.europa. eu/ portal/ page/ portal/ eurostat/ home (accessed 10 February 2012).

Feist M., 2004. Die Landwirtschaft im Wandel (Agriculture in transition). Statistik-Journal: Statistisches Monatsheft Saarland: 3-6.

Gilg A.W., Battershill M., 1999. The role of household factors in direct selling of farm produce in France. Tijdschrift voor Economische en Sociale Geografie 90 (3): 312-319.

Gillmor D.A., 1995. Diversification on farms in the development of marginal regions: Potential opportunities and constraints. In: Byron R. (ed.), Economic features on the North Atlantic margin. Avebury Press, Aldershot: 163-181.

Guth R., 2006. Die Landwirtschaft im Bliesgau (Agriculture in Bliesgau). In: Dorda D., Kühne O., Wild V. (eds), Der Bliesgau - Natur und Landschaft im südöstlichen Saarland. Institut für Landeskunde im Saarland, 42: 171-186.

Guth R., 2007. Die Entwicklung der saarländischen Agrarstruktur (The development of the Saarland's agricultural structure). In: Dörrenbächer H.P., Kühne O., Wagner J. (eds), 50 Jahre Saarland im Wandel. Institut für Landeskunde im Saarland, 44: 177-190.

Kinsella J., Wilson S., De Jong F., Renting H., 2000. Pluriactivity as a livelihood strategy in Irish farm households and its role in rural development. Sociologia Ruralis 40(4): 481-496.

Klemenčič M.M., Lampič, B., Potočnik Slavič I., 2008. The (non)vitality of Slovenian peripheral rural areas. GeograFF 3, Ljubljana.

Klemenčič M.M., 2005. New development strategy of the peripheral homogeneous landscape areas in Slovenia. Dela 24: 185-193. 
Kühne O., 2004. Wetter, Witterung und Klima im Saarland (Weather and climate in Saarland). Institut für Landeskunde im Saarland, Saarbrücken.

Liedtke H., 1969. Grundzüge und Probleme der Entwicklung der Oberflächenformen des Saarlandes und seiner Umgebung (Principles and problems of the development of the surface forms of Saarland and its surroundings). Bad Godesberg.

Logar E., 2012. Contemporary role of part-time farmers: the case study of Voklo. Zaključna seminarska naloga. Ljubljana.

López-i-Gelats F., Milán M.J., Bartolomé J., 2011. Is farming enough in mountain areas? Farm diversification in the Pyrenees. Land Use Policy 28: 783-791.

Maye D., Ilbery B., Watts D., 2009. Farm diversification, tenancy and CAP reform: Results from a survey of tenant farmers in England. Journal of Rural Studies 25: 333-342.

Ministerium für Wirtschaft und Wissenschaft - Referat F/4, 2012. Plan zur Entwicklung des ländlichen Raums im Saarland 2007-2013 (EPLR Saar. Vierter Änderungsantrag (August 2011) gemäß Artikel 6 Abs. 1 Buchstabe a) und Artikel 6 Abs. 1 Buchstabe c) der VO (EG) Nr. 1974/2006)( Plan for rural development in Saarland 2007-2013. Fourth amendment (August 2011) in accordance with article 6, paragraph 1, letter a) and article 6, paragraph 1, letter c) of the order (EG), no. 1974/2006). Online: http://www.saarland.de/ dokumente/thema_strukturfondsfoerderung/SL_Formaler_Antrag_16-02-2012.pdf (accessed 22 January 2013).

Pieniadz A., Renner S., Rathmann C., Glauben T., Loy J., 2009. Income diversification of farm households. Relevance and determinants in Germany. 111 ${ }^{\text {th }}$ Seminar, June 26-27, 2009. Canterbury.
Potočnik Slavič I., 2012. Future agritourism development in Slovenia: Farmers' perspective. Agritourism between embeddedness and internationalisation. File of papers: 88-92.

Potočnik Slavič I., Lampič B., Cigale D., Udovč A., Perpar A., 2012. Potentials of supplementary activities and entrepreneurship in rural areas. Department of Geography, Report on applied research project. Ljubljana.

Schneider H., 1991. Sammlung geologischer Führer (Collection of geological guide). Saarland, Stuttgart.

SORS,2012. Argarian Census 2012. Ljubljana.

Sprenger B., 2002. Landwirtschaft in der Region "West" Irlands. Diversifizierung als Entwicklungprozess und -strategie im ländlichen Raum (Agriculture in the region of "West" Ireland. Diversification as a development process and strategy in rural areas). Unpublished higher diploma thesis at the University of Muenster.

Statistisches Amt Saarland, 2012a. Fläche, Bevölkerung in den Gemeinden am 31.12.2011 nach Geschlecht, Einwohner je km² und Anteil an der Gesamtbevölkerung (Area, population in the communities on $12 / 31 / 11$ by gender, inhabitants per square kilometre and share of total population). Online: http:/ / www.saarland.de/dokumente/thema_statistik/ staa_FB311211.pdf (accessed 22 January 2013).

Statistisches Amt Saarland, 2012b. Preliminary results from the Agricultural Census 2010 Saarland. Unpublished documents of the Statistisches Amt Saarland.

Talbot M., 2012. Farm tourism in Wales: Products, markets and evidence of local benefits. Agritourism between embeddedness and internationalisation. File of papers: 93-106.

Woods M., 2011. Rural. Routledge, Abingdon. 